ORIGINAL ARTICLE

\title{
HPV and histological status of pelvic lymph node metastases in cervical cancer: a prospective study
}

\author{
K Lukaszuk, J Liss, I Wozniak, W Sliwinski, J Emerich, C Wojcikowski
}

J Clin Pathol 2004;57:472-476. doi: 10.1136/jcp.2003.009852

See end of article for authors' affiliations .....................

Correspondence to: K Lukaszuk, Department of Endocrinology, Medical University, Kliniczna $1 \mathrm{~A}$ Gdansk 80-402, Poland; joanna.liss@invicta.pl

Accepted for publication 4 August 2003

\begin{abstract}
Aims: The purpose of this prospective study was to describe the incidence and distribution pattern of human papillomavirus (HPV) DNA in intraoperative dissected lymph nodes and to relate this to the pathological confirmation of metastasis.

Methods: Samples of primary cervical cancer lesions and dissected lymph nodes were obtained from women undergoing surgical treatment. The presence of HPV DNA was detected by the polymerase chain reaction.

Results: Tissue from 79 tumours and 365 lymph nodes was analysed. Metastasis to the lymph nodes was found in 19 cases. Metastasis correlated with the volume of the primary lesion, the depth of cervical and vaginal invasion, and with invasion of the corpus. HPV DNA was found in 60 of the primary lesions and 31 of the lymph nodes. The presence of HPV DNA in the lymph nodes correlated with the volume of the primary lesion and vaginal invasion.

Conclusions: The incidence of HPV DNA in lymph nodes is twice as high as that of histopathologically confirmed metastases. The risk of the presence of HPV DNA and histopathologically confirmed metastases in lymph nodes is related to certain features of the primary tumour.
\end{abstract}

\footnotetext{
C
} arcinoma of the uterine cervix, the fourth most common cancer among women worldwide, is one of the most important health issues for women. Infection with certain oncogenic types of human papillomavirus (HPV) is considered a prerequisite for the development of the disease. ${ }^{1}$ The involvement of HPV in the development of cervical cancer is well established. ${ }^{2}{ }^{3}$ In recent years, there has been growing interest in HPV because of the emerging evidence of its oncogenic potential, particularly in the anogenital tract. ${ }^{1}{ }^{4}$ The prevalence of HPV infection in cervical cancer tissue is estimated to be in the range of $90 \%$, and according to the Eurogin Committee it may be up to $99 \% .^{56}$ In a previous study, we found a lower prevalence in our region. ${ }^{7}$

Early detection of the preinvasive states of the disease leads to uncomplicated treatment and a good survival rate. Unfortunately, in Poland most cervical cancers are detected at advanced, invasive stages. The patients mostly undergo radical hysterectomy (Piver III). The survival of patients after radical hysterectomy depends on several factors, such as tumour size, histological tumour type, lymph node involvement, and the surgeon's skill. ${ }^{9}$ The most important predictive factor seems to be the metastasis status of pelvic lymph nodes. Nevertheless, there are some patients with histopathologically negative pelvic nodes who unexpectedly have recurrences and a short life expectancy. Several studies have focused on the correlation between HPV status and lymph node involvement. ${ }^{10-12}$ Most have involved hybridisation ${ }^{13}$ or the polymerase chain reaction (PCR) to detect HPV-16 and HPV-18.4 101415

\footnotetext{
"Unfortunately, in Poland most cervical cancers are detected at advanced, invasive stages"
}

The purpose of our prospective study was to describe the incidence and distribution pattern of HPV DNA in intraoperatively dissected lymph nodes and pathologically confirmed metastases. We also aimed to identify the histopathological factors related to these parameters.

\section{MATERIAL AND METHODS}

The investigated group comprised 79 patients suffering from cervical cancer (clinical stage IA to IIB), at the Second Department of Obstetrics and Gynaecology, Medical University of Gdansk, Poland. We detected HPV DNA in the primary lesions of 60 patients. HPV-16 DNA was detected in 55 patients, HPV-31 DNA in three patients, and HPV-33 DNA in two patients. External iliac and obturator (EIO) lymph node regions were examined in all of the patients. When histological evaluation of frozen sections gave positive results, adjacent lymph nodes on the involved side were investigated-common iliac and para-aortic (CIP) ones if necessary. The tissues were taken from 79 cervical lesions and 365 lymph nodes groups (table 1 ).

The lymph nodes were processed in their entirety. Slides were taken each $200 \mu \mathrm{m}$. Every second slide was collected for DNA isolation. The remainder were taken for histopathological examination. We did not perform cytokeratin immunohistochemistry routinely.

\section{Isolation of DNA and PCR}

About $25( \pm 5.5) \mathrm{mg}$ of frozen tissue was used for a single DNA isolation. DNA was extracted using silica based chromatography minicolumns (Genomic DNA Prep Plus; A\&A Biotechnology, Gdansk, Poland), according to the manufacturer's recommendations. DNA was stored at $-30^{\circ} \mathrm{C}$. PCRs were carried out using the $\mathrm{pU}-1 \mathrm{M} / \mathrm{pU}-2 \mathrm{R}^{16}$ and MY09/MY $11^{17}$ primer pairs. The $\mathrm{pU}-1 \mathrm{M} / \mathrm{pU}-2 \mathrm{R}$ pair led to identification of a "high oncogenic risk" group of HPV types $16,18,31,33,39,45,52$, and $58 .{ }^{16}$ The sequences of the primers corresponded to the E6 and E7 oncogene fragments of all of these HPV types. The MY09/MYll pair is the

Abbreviations: CIP, common iliac and para-aortic; EIO, external iliac and obturator; HPV, human papillomavirus; PCR, polymerase chain reaction 
Table 1 The presence of human papillomavirus (HPV) DNA and histopathologically confirmed metastases in lymph nodes

\begin{tabular}{lllllllll}
\hline & \multicolumn{7}{l}{ Dissected lymph node groups } \\
\cline { 2 - 8 } & $\begin{array}{l}\text { External iliac } \\
\text { right }\end{array}$ & $\begin{array}{l}\text { External } \\
\text { iliac left }\end{array}$ & $\begin{array}{l}\text { Obturator } \\
\text { right }\end{array}$ & $\begin{array}{l}\text { Obturator } \\
\text { left }\end{array}$ & $\begin{array}{l}\text { Common iliac } \\
\text { right }\end{array}$ & $\begin{array}{l}\text { Common } \\
\text { iliac left }\end{array}$ & $\begin{array}{l}\text { Para-aortic } \\
\text { right }\end{array}$ & $\begin{array}{l}\text { Para-aortic } \\
\text { left }\end{array}$ \\
\hline $\begin{array}{l}\text { Lymph nodes } \\
\text { Total }\end{array}$ & 79 & 79 & 79 & 79 & 24 & 17 & 4 & 4 \\
$\begin{array}{c}\text { Metastatic } \\
\text { HPV DNA in lymph nodes }\end{array}$ & 10 & 6 & 9 & 8 & 1 & 2 & 0 & 0 \\
$\quad$ Total positive in primary lesions & 60 & 60 & 60 & 60 & 21 & 17 & 4 & 4 \\
$\quad$ Positive & 15 & 18 & 16 & 13 & 4 & 4 & 1 & 0 \\
\hline
\end{tabular}

consensus primer pair and permits amplification of the $\mathrm{Ll}$ gene fragment of HPV (for example, HPV types $6,11,16,18-$ $26,30,31,33,35,39,42,45,51-59,66$, and 68).

All of the PCR reactions were performed in $25 \mu \mathrm{l}$ reaction mixtures containing $2.5 \mu \mathrm{l}$ concentrated PCR buffer (10mM Tris/HCl, pH 8.81, $5 \mathrm{mM} \mathrm{MgCl}_{2}, 50 \mathrm{mM} \mathrm{KCl}$, and $0.1 \%$ Triton $\mathrm{X}-100), 0.5 \mu \mathrm{l} 10 \mathrm{mM}$ dNTP, $1 \mu \mathrm{l}$ each of the sense and antisense primers $(10 \mu \mathrm{M}), 0.5 \mu \mathrm{l}(2 \mathrm{U} / \mu \mathrm{l})$ DyNAzyme II DNA polymerase (FinnZyme, Espoo, Finland), $14.5 \mu \mathrm{l}$ distilled water, and $80 \mathrm{ng}(5 \mu \mathrm{l})$ template DNA. The amplification profile was as follows: preliminary denaturation at $94^{\circ} \mathrm{C}$ for two minutes, 30 cycles consisting of denaturation at $94^{\circ} \mathrm{C}$ for one minute, annealing at $55^{\circ} \mathrm{C}$ for two minutes, and extension at $72^{\circ} \mathrm{C}$ for two minutes, followed by a final extension at $72^{\circ} \mathrm{C}$ for five minutes in a programmable thermocycler (Personal Cycler; Eppendorff, Hamburg, Germany). As a positive control we used a previously prepared DNA homologous internal standard, a plasmid containing a modified fragment of the E6 HPV-16 sequence that is coamplified with the wild-type target sequence in the same vial and with the same pair of primers. The coamplification reaction generates two fragments of different sizes that can be clearly distinguished by gel electrophoresis without the need for restriction enzyme digestion. ${ }^{18}$ This method minimises the variability of the efficiency of the PCR technique.

At the detection stage, $10 \mu \mathrm{l}$ samples of PCR products were subjected to electrophoresis on a $10 \%$ polyacrylamide gel and silver stained. Transilluminated gel images were digitalised and analysed by means of the Gel Doc 2000 Documentation System (BioRad, Hercules, California, USA).

The same isolated DNA was also used for p53 mutation analysis. We performed PCR analysis for all 11 exons of the p53 gene. The PCR products were in the range of $213 \mathrm{bp}$ to $356 \mathrm{bp}$. They were used for multitemperature single stranded conformational polymorphism and denaturing high performance liquid chromatography heteroduplex analysis. We obtained good quality products from all materials. Hence, we felt no need to perform additional reactions to check the quality of the material.

\section{Statistical analysis}

STATISTICA for Windows 6.0 (Stat Soft Inc, Tulsa, Oklahoma, USA) was used for statistical analysis. The $\chi^{2}$ test for determination of independence of the variables and multiple logistic regression analysis for predictors of lymph node metastasis were applied. Significance was set at $\mathrm{p}<0.05$.

\section{RESULTS}

The patients had a mean age of 49.1 (SD, 9.7; range, 32-74). Table 2 presents the clinical profiles of the patients.

The following criteria for pathological evaluation were chosen: size of the primary lesion, depth of invasion, invasion of the uterus and parametrium, and lymph node metastasis. Lymph node groups were divided into EIO lymph nodes and common iliac and CIP nodes (CIP). All four EIO groups were taken from 79 patients and 49 CIP groups from 30 patients (table 1). Common iliac lymph node groups were examined in 30 patients - 19 unilaterally and 11 bilaterally. Histological examination revealed metastasis in two of these patients. Table 1 shows the findings in each lymph node group.

There were 33 EIO pathologically confirmed metastases in 19 patients and three CIP metastases in two patients $(3.8 \%$ of the total group). None of the lymph nodes taken from patients who did not have HPV DNA in their primary lesion revealed the presence of HPV DNA. HPV DNA was found in EIO and CIP lymph nodes in 31 of the 60 patients with HPV DNA positive primary lesions. Table 3 shows the incidence of HPV DNA positive lymph nodes by stage.

Table 3 presents the histological features of the cancers in relation to the presence of HPV DNA. There were no significant differences between the histopathological groups in EIO ( $p=0.36)$ and CIP $(p=0.29)$ metastases or the presence of HPV DNA in the EIO $(\mathrm{p}=0.14)$ and CIP $(\mathrm{p}=0.29)$ groups.

Table 2 Clinicopathological findings in patients with cervical cancer

\begin{tabular}{|c|c|c|c|}
\hline & $\begin{array}{l}\text { Total group } \\
(\mathrm{n}=79)\end{array}$ & $\begin{array}{l}\text { Metastatic lymph } \\
\text { nodes }(n=19)\end{array}$ & p Value \\
\hline \multirow{2}{*}{\multicolumn{4}{|c|}{ FIGO stage }} \\
\hline & & & \\
\hline IA & 9 & 0 & \multirow[t]{4}{*}{0.08} \\
\hline IB & 35 & 8 & \\
\hline$\| \mathrm{A}$ & 26 & 10 & \\
\hline$\| B$ & 9 & 1 & \\
\hline \multicolumn{4}{|l|}{ Histopathology } \\
\hline Squamous cell carcinoma & & & \\
\hline Carcinoma in situ & 8 & 0 & \multirow[t]{4}{*}{0.36} \\
\hline Large cell keratinising & 6 & 1 & \\
\hline Large cell non-keratinising & 61 & 17 & \\
\hline Adenocarcinoma & 4 & 1 & \\
\hline \multicolumn{4}{|l|}{ Depth of cervical invasion } \\
\hline $\begin{array}{l}\text { Carcinoma in situ and } \\
\text { microinvasion to } 3 \mathrm{~mm}\end{array}$ & 10 & 0 & \multirow[t]{3}{*}{0.03} \\
\hline Invasion 3-10 mm & 13 & 1 & \\
\hline Invasion >10 mm & 56 & 18 & \\
\hline \multicolumn{4}{|l|}{ Volume of primary lesion } \\
\hline$<1 \mathrm{~cm}^{3}$ & 20 & 0 & \multirow[t]{3}{*}{0.005} \\
\hline $1-10 \mathrm{~cm}^{3}$ & 12 & 2 & \\
\hline$>10 \mathrm{~cm}^{3}$ & 47 & 17 & \\
\hline \multicolumn{4}{|l|}{ Corpus invasion } \\
\hline Not over internal isthmus & 63 & 11 & \multirow[t]{2}{*}{0.006} \\
\hline Over internal isthmus & 16 & 8 & \\
\hline \multicolumn{4}{|l|}{ Vaginal invasion } \\
\hline No & 51 & 6 & \multirow[t]{2}{*}{0.0005} \\
\hline Yes & 28 & 13 & \\
\hline \multicolumn{4}{|l|}{ Parametrial invasion } \\
\hline No & 71 & 16 & \multirow[t]{2}{*}{0.34} \\
\hline Yes & 8 & 3 & \\
\hline
\end{tabular}




\begin{tabular}{|c|c|c|c|}
\hline & $\begin{array}{l}\text { HPV DNA } \\
\text { positive cervical } \\
\text { lesions }(n=60)\end{array}$ & $\begin{array}{l}\text { HPV DNA } \\
\text { positive lymph } \\
\text { nodes }(n=31)\end{array}$ & $\mathrm{p}$ Value \\
\hline Mean age (SD) & $50.6(10.2)$ & $48.2(9.2)$ & 0.06 \\
\hline \multicolumn{4}{|l|}{ FIGO stage } \\
\hline IA & 4 & 1 & 0.44 \\
\hline IB & 27 & 14 & \\
\hline$\| \mathrm{A}$ & 21 & 13 & \\
\hline IIB & 8 & 3 & \\
\hline \multicolumn{4}{|l|}{$\begin{array}{l}\text { Histopathology } \\
\text { Squamous cell } \\
\text { carcinoma }\end{array}$} \\
\hline Carcinoma in situ & 5 & 0 & 0.09 \\
\hline $\begin{array}{l}\text { Large cell } \\
\text { keratinising }\end{array}$ & 5 & 3 & \\
\hline $\begin{array}{l}\text { Large cell non- } \\
\text { keratinising }\end{array}$ & 46 & 25 & \\
\hline $\begin{array}{l}\text { Adenocarcinoma } \\
\text { Depth of cervical } \\
\text { invasion }\end{array}$ & 4 & 3 & \\
\hline $\begin{array}{l}\text { Carcinoma in situ } \\
\text { and microinvasion to } \\
3 \mathrm{~mm}\end{array}$ & 6 & 1 & 0.18 \\
\hline Invasion 3-10 mm & 10 & 5 & \\
\hline Invasion > 10 mm & 44 & 25 & \\
\hline \multicolumn{4}{|l|}{ Volume of primary } \\
\hline$<1 \mathrm{~cm}^{3}$ & 11 & 3 & 0.03 \\
\hline $1-10 \mathrm{~cm}^{3}$ & 10 & 3 & \\
\hline$>10 \mathrm{~cm}^{3}$ & 39 & 25 & \\
\hline \multicolumn{4}{|l|}{ Corpus invasion } \\
\hline $\begin{array}{l}\text { Not over internal } \\
\text { isthmus }\end{array}$ & 46 & 21 & 0.09 \\
\hline Over internal isthmus & 14 & 10 & \\
\hline \multicolumn{4}{|c|}{ Vaginal invasion } \\
\hline No & 34 & 13 & 0.01 \\
\hline Yes & 26 & 18 & \\
\hline \multicolumn{4}{|l|}{ Parametrial invasion } \\
\hline No & 53 & 26 & 0.26 \\
\hline Yes & 7 & 5 & \\
\hline
\end{tabular}

The correlation between EIO and CIP metastases and local invasion (cervix, corpus, vagina, and parametrium) was analysed. EIO metastases were strongly related to the depth of cervical stromal invasion $(p=0.03)$, corpus invasion $(\mathrm{p}=0.006)$, and vaginal invasion $(\mathrm{p}<0.001)$. EIO metastases were not related to parametrial invasion $(\mathrm{p}=0.34)$. CIP metastases were related only to parametrial invasion $(\mathrm{p}=0.01)$. The presence of HPV DNA in EIO was strongly related to vaginal invasion $(p=0.01)$ and volume of the primary lesion. The presence of HPV DNA in CIP lymph nodes was not related to corpus invasion $(\mathrm{p}=0.15)$ or parametrial invasion $(\mathrm{p}=0.09)$ (table 4$)$.
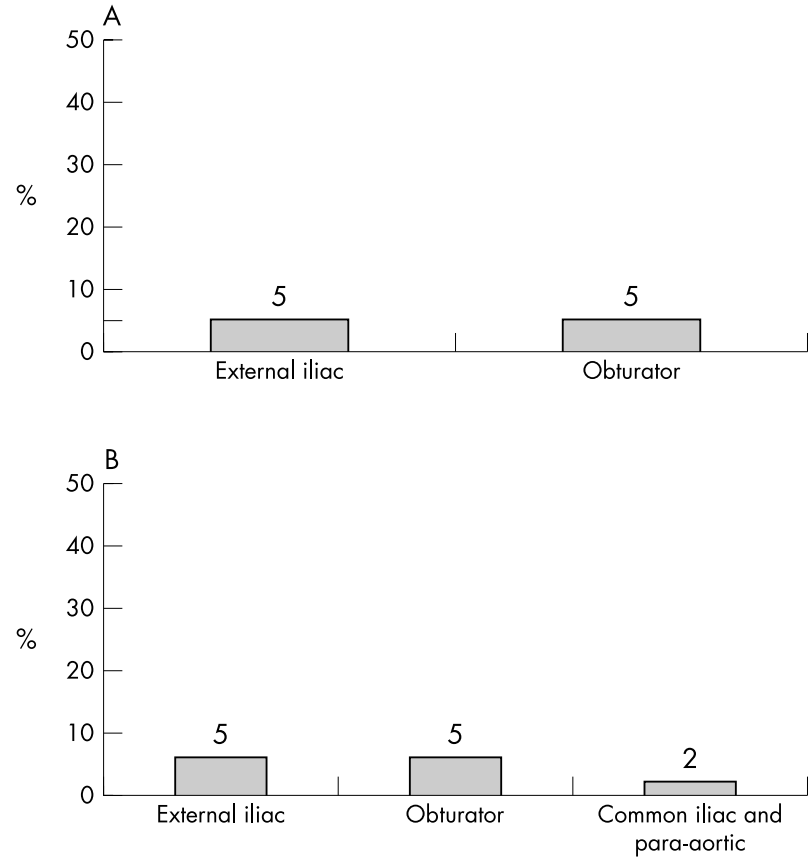

Figure 1 The prevalence of solitary lymph node involvement (\%). (A) Histopathologically confirmed metastasis, (B) the presence of human papillomavirus DNA.

EIO metastases were strongly related to the volume of the primary lesion $(p=0.005)$, whereas CIP metastases were not. The presence of HPV DNA in EIO was related to the volume of the primary lesion $(p=0.03)$ but this was not the case for CIP.

All factors that were shown to be related to EIO and CIP metastasis by univariate analysis were included in multiple logistic regression analysis. Vaginal invasion $(p=0.001)$ was found to be a significant risk factor for EIO metastasis and the presence of HPV DNA in EIO. In the case of CIP invasion, no factors were significant risk factors for metastasis and the presence of HPV DNA.

Figure $1 \mathrm{~A}$ and $\mathrm{B}$ shows lymph node metastasis and the presence of HPV DNA. Solitary lymph node metastasis was found in the external iliac (five patients) and obturator (five patients) groups. HPV DNA was also found in the single common iliac (one patient) and para-aortic (one patient) groups.

\section{DISCUSSION}

There are two modalities for cervical cancer primary treatment: radiotherapy and surgery. The choice of treatment

\begin{tabular}{|c|c|c|c|c|c|c|}
\hline & $\begin{array}{l}\text { Total CIP } \\
(n=28)\end{array}$ & $\begin{array}{l}\text { Metastatic CIP } \\
(n=2)\end{array}$ & $\mathrm{p}$ Value & $\begin{array}{l}\text { Total HPV DNA } \\
\text { positive }(n=25)\end{array}$ & $\begin{array}{l}\text { HPV DNA positive } \\
\text { CIP }(n=9)\end{array}$ & p Value \\
\hline \multicolumn{7}{|l|}{ Corpus invasion } \\
\hline $\begin{array}{l}\text { Not over } \\
\text { internal isthmus }\end{array}$ & 21 & 1 & 0.39 & 19 & 7 & 0.15 \\
\hline Over internal isthmus & 7 & 1 & & 6 & 2 & \\
\hline \multicolumn{7}{|c|}{ Vaginal invasion } \\
\hline No & 18 & 1 & 0.66 & 15 & 5 & 0.45 \\
\hline Yes & 10 & 1 & & 10 & 4 & \\
\hline \multicolumn{7}{|l|}{ Parametrial invasion } \\
\hline No & 26 & 1 & 0.01 & 23 & 7 & 0.09 \\
\hline Yes & 2 & 1 & & 2 & 2 & \\
\hline
\end{tabular}


depends on the stage of the disease. Our surgery procedures are limited to patients with stages I and II. The outcome depends not only on nodal status and tumour size, but also on paracervical involvement and histological type. Pelvic lymph node status is considered to be the most important predictor after FIGO staging. ${ }^{19}$ Unfortunately, non-invasive diagnostic procedures (computed tomography or magnetic resonance imaging scans) are not applicable because $20-50 \%$ of metastatic lymph nodes are not enlarged. ${ }^{20}$ On the other hand, even non-enlarged, non-metastatic cancers sometimes show worse outcome than would be expected from clinical staging. Hence, many researchers evaluate the presence of HPV DNA in lymph nodes in such cases. ${ }^{21}$

We found HPV DNA in 60 of 79 cervical lesions, mostly HPV-16 (55 patients). HPV-16 was found in all adenosquamous carcinomas and adenocarcinomas and in all keratinising lesions. These findings confirm the results published by Park et al. ${ }^{14}$ We also noted a lack of HPV-18 in our material. Park et al suggested that the ethnic group of the patients may have influenced their results. ${ }^{14}$ We cannot confirm this. A low prevalence of HPV-18 is consistent with our findings in cytological screening. We found only two cases (of a total of 56 patients with detected HPV infections) of HPV-18 in samples from 1664 asymptomatic women (unpublished data, 2004).

The prevalence of HPV infection in cervical cancers is mostly reported as high. ${ }^{22}$ Eurogin experts have suggested that it can be as high as nearly $99.9 \%{ }^{5}$ We did not find such a high prevalence of HPV in our patients with cervical cancer. We confirmed the results of Cavuslu et $a l^{22}$ and we found histopathologically confirmed metastases to lymph nodes only in HPV positive cervical cancers ( $p=0.005)$.

The features characterising tumour local invasion, such as the depth of cervical stromal invasion, corpus invasion, and vaginal invasion (similar to those observed in the GOG study), are associated with a higher possibility of EIO metastasis.9 Surprisingly, in our study, parametrial invasion did not increase the frequency of lymph node invasion $(p=0.34)$. This observation has not been supported by others. Parametrial involvement is always an independent risk factor of lymph node metastasis. ${ }^{20}$ Our finding may be a result of having a small subject group—only eight patients with parametrial involvement.

\section{"Finding HPV seems to be a much more sensitive method of detecting lymph node involvement than normal histopathological examination"}

In our study, the risk factor of the presence of HPV DNA in the lymph node was similar to the risk factors for histological metastases. We found a significant association between local tumour invasion features (corpus invasion and vaginal invasion) and the presence of metastasis in the lymph nodes.

The presence of HPV DNA in lymph nodes is usually, but not always, connected with metastasis from HPV positive tumours. In the case of cancer free nodes the presence of HPV DNA could be explained by: (a) micrometastases not histopathologically detected, (b) micrometastases digested by immunocompetent cells, or (c) free HPV particles resulting from lymphoidal spread. ${ }^{4}{ }^{14}$ The estimation of relative amounts of different HPV genes present in the primary lesion $^{12}$ and in HPV DNA positive nodes could be helpful in resolving this problem. Most authors suggest that HPV DNA present in cancer free and metastatic lymph nodes is the result of undetectable and detectable tumour spread. ${ }^{21}$ The retrospective results presented by Pilch et al should be investigated prospectively for confirmation of the clinical relevance of the detection of HPV DNA in lymph nodes. ${ }^{21}$ In
Take home messages

- Human papillomavirus (HPV) DNA was found in the primary tumour in 60 of the 79 patients with cervical cancer

- The incidence of HPV DNA in lymph nodes is twice as high as that of histopathologically confirmed metastases

- The presence of both HPV DNA and histopathologically detected metastases in lymph nodes is related to the same features of the primary tumour-vaginal invasion and volume of the primary lesion

our samples, at every FIGO stage analysed, the incidence of HPV DNA was about twice as high as the incidence of metastases. Furthermore, we found no cases with HPV DNA in the lymph nodes where HPV DNA was not present in the primary tumour. We also found no cases with lymph node metastases where HPV DNA was not present in the primary tumour. The distribution patterns of lymph node metastases and HPV DNA in lymph nodes were very similar. These findings support the usefulness of the presence of HPV DNA in cancer free lymph nodes as a predictive factor of distant tumour spread. Finding HPV seems to be a much more sensitive method of detecting lymph node involvement than normal histopathological examination. The only condition required is the presence of HPV DNA in the primary cervical tumour.

Deppe et al suggested the possibility of direct lymph drainage to para-aortic lymph nodes. ${ }^{23}$ We could not evaluate this possibility in our material because in our protocol metastases in regional lymph nodes were an inclusion criterion for para-aortic dissection. However, in one patient we found HPV DNA in the CIP lymph nodes although neither HPV DNA nor metastases were present in the EIO nodes. This supports the possibility of solitary lymph node metastasis to the common iliac. ${ }^{20}$ We also found a single patient in whom HPV DNA was present in the common iliac lymph node but there was no involvement of other lower lymph nodes. In our opinion, common iliac lymph nodes should be included in regional lymph nodes. They should also be dissected during routine invasive cervical cancer procedures.

Bilateral dissection of pelvic lymph nodes causes many postoperative complications and inconvenience to the patient. The crucial role of sentinel lymph nodes in limiting the extensiveness of surgery has been emphasised by many authors. ${ }^{24}$ Sakuragi et al suggested that the obturator lymph nodes are sentinel lymph nodes. ${ }^{20}$ We cannot confirm such a statement. We found an almost equal frequency of solitary lymph node metastasis and the presence of HPV DNA in solitary lymph nodes in the obturator and external iliac lymph node groups. The results in the HPV positive group indicate that prognostic parameters and even biopsies of the lymph nodes could lead to molecular analysis that is very sensitive and unambiguous. It could be performed, for instance, during laparoscopy before the main operation and should concern obturator and external iliac lymph node groups, in addition to CIP nodes.

\section{Authors' affiliations}

K Lukaszuk, I Wozniak, C Wojcikowski, Department of Gynaecological Endocrinology, Medical University, Gdansk 80-402, Poland

$\mathrm{J}$ Liss, INVICTA - Laboratory of Molecular Biology, Prophylactic Centre, Gdansk 80-895, Poland 
W Sliwinski, J Emerich, Department of Gynaecology, Medical University, Gdansk

\section{REFERENCES}

1 Fuchs PG, Girardi F, Pfister H. Human papillomavirus 16 DNA in cervical cancers and in lymph nodes of cervical cancer patients: a diagnostic marker for early metastases? Int J Cancer 1989;43:41-4.

2 zur Hausen $\mathrm{H}$, Schneider A. The role of papillomaviruses in human anogenital cancer. In: Salzman NP, Howley PM, eds. The papovaviridae. The papillomaviruses. New York: Plenum, 1987:245-63.

3 zur Hausen $\mathbf{H}$. Molecular pathogenesis of cancer of the cervix and its causation by specific human papillomavirus types. Curr Trends Microbiol Immunol 1994;186:131-56.

4 Kobayashi Y, Yoshinouchi M, Tiangi G, et al. Presence of human papillomavirus DNA in pelvic lymph nodes can predict unexpected recurrence of cervical cancer in patients with histologically negative lymph nodes. Clin Cancer Res 1998:4:979-83.

5 Monsonego J. Global challenges of cervical cancer prevention. Expert meeting Eurogin 2000 Congress, Paris, 5-9 April 2000 (http:// www.eurogin.com).

6 Walboomers JM, Jacobs MV, Mason M, et al. Human papillomavirus is a necessary cause of invasive cervical cancer worldwide. J Pathol 1999; 189:12-19

7 Liss J, Emerich J, Lukaszuk K, et al. The use of PCR technique in the evaluation of the frequency of HPV infection in vulvar and cervical carcinoma. Ginekolo Pol 1998:69:330-4.

8 Fuller AF, Elliott N, Kosloff C, et al. Determinants of increased risk for recurrence in patients undergoing radical hysterectomy for stage IB and IIA carcinoma of the cervix. Gynecol Oncol 1989;33:34-9

9 Delgado G, Bundy B, Zaino R, et al. Prospective surgical-pathological study of disease-free interval in patients with stage IB squamous cell carcinoma of the cervix: a gynecologic oncology group study. Gynecol Oncol 1990;38:352-7.

10 Czegledy J, Poka R, Veress G, et al. Amplification of human papillomavirus type 16 transforming genes from cervical cancer biopsies and lymph nodes of Hungarian patients. J Clin Microbiol 1992;30:233-6.

11 Lancaster WD, Castellano C, Santos C, et al. Human papillomavirus deoxyribonucleic acid in cervical carcinoma from primary and metastatic sites. Am J Obstet Gynecol 1986;154:115-19.
12 Lukaszuk K, Liss J, Woźniak I, et al. Human papillomavirus type 16 status in cervical carcinoma cells DNA given by multiplex PCR. J Clin Microbiol 2003;41:608-12.

13 Ikenberg $H$, Teufel G, Schmit B, et al. Human papillomavirus DNA in distant metastases of cervical cancer. Gynecol Oncol 1993:8:56-60.

14 Park JS, Rhyu KS, Kim CJ, et al. Presence of oncogenic HPV DNAs in cervical carcinoma tissues and pelvic lymph nodes associated with proliferating cell nuclear antigen expression. Gynecol Oncol 1996;60:418-23.

15 Czegledy J, losif C, Forslund O, et al. Detection of human papillomavirus DNA in lymph nodes extirpated at radical surgery for cervical cancer is not predictive of recurrence. J Med Virol 1998;54:183-5.

16 Fujinaga Y, Shimada M, Okazawa K, et al. Simultaneous detection and typing of genital human papillomavirus DNA using the polymerase chain reaction. J Gen Virol 1991;72:1039-44.

17 Rady PL, Chin R, Arany I, et al. Direct sequencing of consensus primer generated PCR fragments of human papillomaviruses. J Virol Methods 1993;43:335-50.

18 Lukaszuk K, Liss J, Witkowski J, et al. Recombinant DNA templates as a competitive internal standard in qualitative PCR of human papillomavirus detection in cervical cytology. Polish Journal of Gynaecological Investigations 2002;5:253-60.

19 Bleker OP, Ketting BW, van Wayjen-Eecen B, et al. The significance of microscopic involvement of parametrium and/or pelvic lymph nodes in cervical cancer stage lb and lla. Gynecol Oncol 1983;16:56-62.

20 Sakuragi N, Satoh C, Takeda N, et al. Incidence and distribution pattern of pelvic and paraaortic lymph node metastasis in patients with stages IB, IIA and IIB cervical carcinoma treated with radical hysterectomy. Cancer 1999:85:1547-54.

21 Pilch H, Gunzel S, Schaffer U, et al. Human papillomavirus (HPV) DNA in primary cervical cancer and in cancer free pelvic lymph nodes-correlation with clinico-pathological parameters and prognostic significance. Zentralb/ Gynakol 2001;123:91-101.

22 Cavuslu S, Goodlad J, Hobbs C, et al. Relationship between human papillomavirus infection and overexpression of $\mathrm{p} 53$ protein in cervical carcinomas and lymph node metastases. J Med Virol 1997;53:111-17.

23 Deppe G, Lubicz S, Galloway BT, et al. Aortic node metastases with negative pelvic nodes in cervical cancer. Cancer 1984;53:173-5.

24 Levenback C, Coleman RL, Burke TW, et al. Lymphatic mapping and sentinel node identification in patients with cervix cancer undergoing radical hysterectomy and pelvic lymphadenectomy. J Clin Oncol 2002;20:688-93. 